\title{
The Unsurveyed World, 1874
}

\section{Staff-Commander T. A. Hull R.N}

To cite this article: Staff-Commander T. A. Hull R.N (1875) The Unsurveyed World, 1874, Royal United Services Institution. Journal, 19:80, 48-73, DOI: 10.1080/03071847509415958

To link to this article: http://dx.doi.org/10.1080/03071847509415958

\section{曲 Published online: 11 Sep 2009.}

Submit your article to this journal

Џll Article views: 4

Q View related articles $\longleftarrow$ 


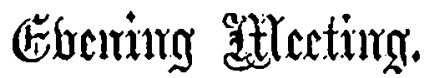

Monday, February 1, 1875.

VICE-Admirar R. COLLINSON, C.B., Vice-President, in the Chair.

NAMES of JIEIIBERS who joined the Institution between the 10th January and 1st February inclusire.

LIFE.

Salmond, F. Mr., Captain 21st R. N. B. Fusiliers.

I3ayles, J. A., Jajor late 52nd Regiment.

IIcatlicote, C. Geo., Licutenant 5th Fusiliers.

ANNUAL.

Srale, John T., Captain 7th IIussars. Dismin, S. O., Lieutenant R.N.
IIloste, D. E., O.B., Colonel R.A. Ise Grand, F. G., Captain R.M.L.I.

\section{THE UNSURVEYED WORLD, 1874.}

\section{By Staff-Commander T. A. HuLL, R.N., Superintendent of Charts, Admiralty.}

\begin{abstract}
"From constantly comparing maps and charts, and noting the progress and direction of discorery, Columbus was led to perccire hom much of the Forld remained unknown, and to meditato on the means of exploring it." - Washington Ircing.
\end{abstract}

Ir lhas been remarked by a modern historian, in reflecting on the bril. linnt decds and stedfast valour of our sailors daring the wars of Nipolcon, that the Nary of this country was destined to riral in the annals of the rorld the celebrity of the Roman Legions.

Bat it is not in deeds of arms alone that these distingnished bodies of men aro rirals. As in old time "ont of the eater came forth meat, and out of the strong came forth sircetness," so ont of the horrors of war come arts essential to the blessings of peace. To insure the success of their warlike designs, both Roman soldier and English sailor added considerably to the future comfort and safety of humanity-the Roman, by making roads; the Englishman, by con-1 structing charts.

What roads are to the soldier, charts are to tho sailor, and it is easy to prophecy that England's charts will acquire a greater fame thani cren the Roman roads.

All of you who are accustomed to drive, know the comfort of a good road, on a dark night. Raise that comfort to the highest power of which your imagination is capable, and you will have some slight ides: 
of the solace that a trustworthy chart is to the captain of a ship in a dark night and in a gale of wind.

Bat charts, like roads, require constant attention and repair. The roads made by tho Romans in Great Britain gradually fell into decay, and the attempts that were now and then made to repair them were insufficient to prevent England falling into a worse stato with respect to its highriass, than most other Earopean countries.

It is to arrest a similar decay in the charts of our occan highways, that I hare, with the kind permission of the Conncil, ventured to intrado myself on your notice this ovening.

It is, I am sorry to say, too often the fashion when matters do not go quite as we liko them, for us Englishmen to find fault with the Gorernment of the day, when the blame really lies upon our own shoulders. The zeal, ability, and managoment displayed by tho various Hydrographers hare been most severely taxed in straggling against the rigid economy which the people of this conntry desired to hnve carried out in tho pablic service. I am therofore most anxions this erening to persuado my andienco to take an interest in this, to Englishmen, important subject, and request their representatires in Parliament to increase the scientific rote, so that the surreging wants of the nation and mercantile community may be promptly carried out.

I flatter myself that I may be successful, for as far back as Janaary, 1873, I detected a slight turning of the tide, when a leader in the Daily Netws pointed out that althougl our mercantilo Nary had steadily increased from 4 to 7 million tons, our surreying forces had as stcadily decreased. And yet the Hydrographic Office is in a great measure self-supporting, as the sale of our charts and books is very large, and might bo mado larger, by using the ordinary mercantilo means of increasing the size of an establishment, to meet the wants of the customers.

In December, 1873, the letter of Sir Bartle Frere, in reply to one from Mrr. Gladstone, on the Arctic Expedition, came to cheer and enconrage the Surveying Service; one portion of it so fully sets our caso in its true light, that I must ask you to allow mo to quote it.

After a short preamble, Sir B. Frero writes as follows :-

"You will, I am sure, pardon mo for taking exception to the cxpres" sion in your letter which indicates an opinion that royages for surrey " or discovery are not strictly 'professional nafal sertices.' I beliore "that in these days, when it is so difficalt to find a seaman's training "for our young Officers and men, when so much of tho work is done by "machinery, there are few better naral schools than a surveying " ship; and that, if such ships wero multiplied, not only would coin"merce benefit, but your men-of-war mould be better supplied with "practical seamen, both among men and Officers, than is possible at "present.

"This is still more the case with regard to any Arctic rojage of "discovery. Servico in the Aretic Seas, under nny conditions, is one " of the best possible schools for seamen, and is one of the ferr schools

"which now remain by which a thorough seaman can be formed, quite

" cqual to the best men of former days.

roL, XIs. 
"MLorcover, as a matter of fact, some of our reiy best practical "Offeers aro men who distinguished themselves in Aretic exploration; " and I doubt whether there is a single hour of any Arctic royage of "discovery which, in a strictly professional point of view, nay not " bo considered well spent as training for any naval scrricc."

I hope, Sir, to be able to show how correct were Sir Bartle Frcre's assertions.

The above letter called forth another vigorous articlo from the Daily Neves, in Janunry, 1874; while tho Geographical Mrtgazine, edited by Mr. Clements NIarkham, one of the Secretaries of the Roynl Gcographical Societs, in an ablo articlo in the April namber, on the "Hydrograplical "Department of the Admiralty," called attention to the reductions in the scientific force. In the July number a similar article on the "Indinn "Marine Surreys" showed that although it was one of the obvious dutics of a country with an extensire seaboard and a great seaborne trade, to provide for tho safety of the ressels which frequent her ports, by the provision of lighthouses and buogs, and above all, by tho preparation of reliable charts and sailing directions, yet nothing had been dono for a space of 12 years for the coasts of our Indian Empire.

It was thus that the chango in pablic opinion, actiug upon a mind I fear more enthasinstic than intellectual, nerred me into drawing up this paper, and constructing the chart beforo you.

On this ontline chart of the world I have endenroured, by means of colour, to depict, faithfully, the present state of hydrography; and I fear that there will bo little diffeulty in showing that the titlo giren to the chart, is a correct one. The surreyed consts aro coloured red; thoso only partially surresed, blue; while consts that have mercly been explored, are coloured broun.

On the small chart (Plate II) which accompanies, this paper howerer, the shores, marked by a heavy coast line, aro pronounced to bo surreyed; the shaded consts are only partially surrejed, i.e., although the charts of those regions answered tolerably well for the timo when they were made, modern progress, steam, and the increase of shipping, require that theso coasts shonld be moro thoronghly examined. A large portion of the chart is drawn only in fine outline; this indicates that such portions have not been surveyed; they hare been merely explored. Tho bridle-paths or log-roads of tho occan, cat and laid with wonderful energy and ability by such men as Dampier, Cook, Vanconver, and others, whom Froude has well spoken of as "England's "forgotten worthies." They are forgotten, perhaps, by tho mans, but well-known to a fer, who, although feeling themsclres rory far the inferiors of these Vikings in ability, are nerertbeless animated by the same earnest wish to do their work at homo and abrond fearlessly, against all risks, and to whom such sailors become patterns worthy of cren the faintest imitation.

In tho chart, from the vastness of the sabject, I fear many crrors will bo detected by sailors knowing the respectivo consts; I shall only bo too glad to find that there should bo more thick coast lino upon the chart, but I trust no ono will be able to remore that line, or the shading. 
The slips npon the chart shor the stations of the threo regular surrcying ressels at present in commission; the crosses show the herd:quarters of Olficers stationed on sliore, doing their best with hired boats and crews. The large cross in the Bay of Bengal, represents the Indian Marine Surrey, lately established by Lord Salisbury.

Warino surveys aro carried on, cither by regular men-of-war fitted for the purpose, or by small hired ressels with hired crews, the latter being alopted whero practicable, with a viow to cconomy. ' I will, therefore, first call your attention to the surreys at present in progress, takien chicfly from tho Hydrographer's report to tho Rogal Geographical Society in May last.

First, there is the "Shearwater," nuder Commander Wharton, latels employed npon the east const of Africa, and in taking. the Transit of Venns-obserrers from the Cape to Rodrigues. The "Nassau," under Lioutenant Gray, is still working upon the east coast south of Zanzibar, where their labonrs hase lately been rewarded by the discovery b5 Nerigating Lieutenant J. Dixon of a fno harbonr ; and the "Sylvia," stationed in Japan, where Captain St. John and his ablo assistant, Navigating-Lientenant W. Pearce, are ordered to survey the southern coast of Nipon. The half ship, on tho east coast of England, represents the "Porcupine," wherein Staff-Commander John Parsons, with two assistants and a hired crew, have been closely sounding the approaches to Harwich; the work extended from Orfordness to tho Nazc, and included seaward as far as the Shipwash and Ganflect Sands. A similar close examination of the shores from the South Foreland to Dungeness was made; the soundings extending from the coast from threo to fivo miles. Dorer Bay was also surreyed in close detail, in anticipation of the proposed harbour-morks, in continnation of tho Admiralty Pier.

Staff-Commander D. Hall made-during 1873 , in addition to local surreys of the Medina River and Corres Roads, a minute examination of the bar at Portsmouth Harbour. This surrey, consequent on the dredging operntions of $1871-2$, shows that tho proposed depth of 20 feet at low watei ordinary spring-tides, has, with the exception of a fer spots of 19 feet, been realised. The completion of this ralnable channcl into our great naval arsenal cannot bo overrated. Up to 1863, a line-of-battlo ship was obligcd to discharge her guns in order to proceed from Spithend to Portsmouth Harbour; now any ship, drawing 25 ' feet, can enter at three-hours' flood, and the heariest draft ship, at high water.

Eerst Coast of Ircland.-Strff-Comminder Kerr and two assistants, in a small lired steamer, have made a patient examination of tho off-lying shonl banks between the Tuskar Rock and Wicklow Head. The changes that had taken placo in these banks, since their. sarrey in 1844 by the late Captain Frazer, haro been of sufficient importanes to navigation to demand this re-survey, and to necessitate their rebuosage, a work now performed by the Commissioners of Irish Iights.

An examination of the bar at TVexford, at Kingston Harbour, the bar of the Liffor River, and the new cutting through the bar of Longh Carlingford, formed also a portion of the season's work. Gratifying 
marks of improvement present themselves in the two last-named localities. Tho bar of the Liffey has now 15 feet at low-water-springs over a breadth of two cables, and a narrow lane of $17 \frac{1}{2}$ feet. In 1800 , the greatest depth was but $5 \frac{1}{2}$ fect; in 1856, 13 fect. Lough Carlingford Bar, with its cutting of 400 feet wide, and a depth of 18 feet, opens up a fine harbour. A line of steam-vessels now runs to the new harbour-works and railway at Grecnore, on tho west side of the Lough.

Navigating Ticutenant MFillard is continuing the survey of the north coast of Sicily, on which Commander Wharton in the "Shearwater" was engaged, before sho was detached to increase the squadron required off Zanzibar.

West Indies.-Staff-Commander George Stanley and one assistant, in a hired schooner, have been engaged on the south coast of Jamaicá. Tho chief operations of the survey were the charting and sounding off to the 100-fathom line, the coast between Port Royal and Morant Point-a work of difficulty, owing to the ficrco trade-rinds which usually blow in that district. In the latter part of 1873, yellow ferer, of a malignant type, broke out at Kingston and Port Royal. Many deaths onsued, and among the victims was a promising joung Officer, Narigating-Licutenant Thompson, attached to the surrey.

Ncovfoundland.-Narigating-Lientenant William Maxwell and party, in the hired steam-vcssel "Gnlnare," havo been actively.engaged in various localities. On the south coast the surrey progressed 20 miles to the eastrrard. A re-surrey of Port Hood, in Cape Breton Island, owing to great changes in the depth of water in certain parts, was mado at the request of the Government of the Dominion of Canada. The coast of Labrador, from Cape St. Lewis to the latitude of $51^{\circ} \mathrm{N}$., was also examined, tho prominent head-lands fixed, and outlying islands surreyed. The slort time during which this survey can be profitably prosecnted makes it an arduous scrvice. The difficulties of the scason's work at the begiuning were further enhanced by the immense number of icebergs aground along the shore.

In Western Australla, Navigating-Lientenant Archdeacon and his assistant have surreyed, in laborious detail, the entrances and approaches to Cockburn Sound, Owen's Anchorage, and Gago Roads, with the view to certain harbour-works in the interests of the colony. The service on this exposed const in whale-boats, and with crews found by the colony, by which slender means tho duty was accomplished, is wortly of record. The party hare now completed the northern and restern approaches to Swan Rirer, and survejed the small, but rising port of Champion Bay.

In South Australia, Staff-Commander Howard and stafi have completed the soundings off the southern shores of Kangaroo Island. In Spencer's Galf, several islands and dangers seaward of Port Lincoln were examined, and soundings in detail were taken. The const-line from Capo Catastrophe to Point Aroid, the inner waters of Coffin's Bay, and the sea-const thence to Point Drummond, hare also been surreyed. Soundings off the wild line of const, westward of Cape Catastrople are now in progress. 
Victoria.-The sarreying party under Staff-Commander H. J. Stanles have been chiefly emplojed in completing the coast-line of King Island at the western entrance of Bass's Strait, and in sounding around. The baink of soundings, extending seawaird from King Island in the direc. tion of Portland Bay, was found to extend 30 and 40 miles from the const, and then to drop suddenly to depths greater than 150 fathoms. This bank of soundings should afford material aid to the navigator making the land in thick weather.

Queensland.-Staff-Commander Bedwell, in tho hired schooner "Pearl," aided by a steam launch, is stendily working northward towards Torres Straits. Port Bowen, Island Head, Strong-tide Passages, Shoal-water Bay, Broad Sound, and sereral islands of the Northumberland group, have been included in the year's surver. Navigating-Lieutenant Connor, detached from the "Pearl," has been emplojed surreying the Brisbane Rirer, and the entrance of Endearour River where Cook refitted the "Endearour" in 1770, after nearly losing the ship on a reef in the neighbourhood.

South-icest Pacific.-The cross near the Fiji Islnads represents Lieatenant L. S. Dawson, R.N., our itinerant survejor in this part of the rorld. Lieuteuant Dawson is placed at the disposal of Commodore Goodenough, to carry out such work as may be most urgently required. I can answer from some ycars' experience of this Officer, that if ho had a ship under his command, he would not only be able to do more work, but would also soon turn his Ofticers into Nautical Surresors.

The large cross in the Bay of Bengal represents the Indinn surres lately established under Commander A. D. Taylor. I shall treat of this surrey farther on.

In addition to the abore, wo bare the assistance of a few zealous Officers of the Royal and Ifercantile Navies; tho Surreying Serrice like the Nary and Army possessing its voluntecrs. Their scrvices will be presently alluded to.

Returning to the coasts, those of England mny be considered as surreyed; but let me impress upon your minds, that owing to their shifting nature, tho sands surroanding our shores require constant watching and examination. A late celebrated minister once remarked, as a reason for reducing the surveying staff, "That when he had last "gone out of office, twenty jears before, he had left an Officer sur. " veying the mouth of the I'hames; and on his return to Whitehall he "found the same Officer employed upon the same duty."

Now, politically, I beliero this was a very clever remark, but liydrographically it was a littlo dull, for the mouths of rivers are often found to be as changeable as the minds of men. To keep the British charts in good working order, a strong surreying staff is not merels necessnry, but absolutely indispensable.

The dark line naturally prevails orer European coasts. Datch and French coasts are so marked, but a glance at the charts will shon: that shade is, as a general rule, the correct symbol for the sliures of the Peninsula. In the Mediterranean. the coasts of Algieres and 
Tanis are surreyed as far as the Galf of Kabes; the coast, then, with the exception of the harbour of Tripoli, is little better than explored or unsurresed until wo rench Benghazi; thoneo to Aloxandria it may be called partially done, while from Alexandria to Iskanderoun, we are again tupon a well surrejed shore.

Bnt I. will not weary you with a description that I fear would bo tedions; to make the paper, therefore, more interesting, we will return to Plymouth, take ship, and go a voyage round the world, noting as we sail along, tho sarreyed and unsurveyed shores that wo pass.

Madeira and tho Canaries may bo considered as doue; tho Capo de Verd Islands, lowerer, requiro further examination; on reaching the coast of Brazil, wo first anchor at Bahia, a sarresed port, with howcrer somo unexamined shoal-ground on. the western side of tho entrance.

Pushing onward to Rio wo are still on the black line. Learing that beatifal liarbour, wo enter a partiall 5 -surreyed region until we come to the River Plate, of which a surroy is mach required; it was patched a fer ycars back by Licatenant Dawson working in a gan-ressel detached for the purpose; the French and Americans have also contributed portions, but it has never been fairly surreyed thronghout.

Tho partial survey of $\lambda$ dmiral Robert FitzRoy carries ns next to Cape Virgins. In mentioning the name of FitzRoy, I must pause to admiro how unuch was dono by this earnest sarreyor, who with comparatively small means, and in an extraordinarily short tinse, mapped the Continent of South America from the Rirer Plate in the Atlantic, to the River Guajaquil in the Pacific.

Admiral Sir Francis Beanfort, in his return made to the House of Commons in 1848, remarks, "That all that is immecliately zcanted of "theso shores has been already achioved by the splendid surrey of "Captain Robert FitzRoy:"

I call jour attention to the important words "immediately rcantcl," that was upwards of a quarter of a century ago, beforo tho day's of steamships, 375 feet long, and beforo the Strait of Magellan was the high road to the Pacific Ocean.

Rounding Capo Virgins, wo enter the Strait of MIagellan. Txeellent charts, constructed b5 Captain R. Mrajne, R.N., and his able Lientenant Francis Gray, carry us safely onward for 110 miles, when we again enter the sladed or partially surreged ground. After passing the southern bend of the straits, the "Royal Naral Reserve" comes to the assistance of tho Hydrographic Office, in the person of Lientenant S. T. Lecky, a worthy Fellom of the Royal Geographical Socicty, and a Captain in the service of the Pacific Stcan Navigation Company. This gentlemau, ably assisted by Officers whom he had trained to the work, has furuished as with a running surrey (that would reflect redit on any Admiralty Survoyor) extending from Cape Cross-Tide to Cape Pillar, a distance of 100 wiles. In his last voyage he mado several valnable corrections and additions to our charts on the coast to the northward of Capo Pillar. I may here mention that Captain Lecky acqnired his knowledgo of nantical survering when in the service of the Honourable East India Company. 
IVe should like to continue our royage by the inner channels leading northward of Magellan; but thicre are orders from tho owners against using theso partially surresod waters, and wo aro reluctantly forced into the Pacific (an ocean by no means worthy of its name in tho vicinity of Cape Pillar), with a loss of fuel and comfort, and with rreat ricar and tear to ship and engines.

Captain Mayne's work combined with that of Captain Lecky (whoso surrey cnabled the Hydrographic Offico to connect the detached works of King and FitzRos), supply a tolerablo chart of tho Strait of Magollan; but the rapidly increasing traffic of large and powerfnl steamers through this great connecting link between Europe and tho western coasts of America, points urgently to the necessity of completing the surres of Magellan Strait, and tho channels northward to the Gulf of Peũas.

Pursuing our courso along the coast of Chile, whose increasing trato with this conntry would bo much benefited by better charts, we toach at Valpamiso, Callao, und Payta; but it is not until we reach tho Rifer Gnayaquil that re aro in tho ricinity of a coast, of which wo possess reliable charts. From Ganyaquil to. Panama we are on the dark line, and, therefore, venturing nearer to the shore, wo can coast along one of the most heautiful and interesting parts of the globe; passing In Plata Island, whero Drake divided the spoils of the Cacafuego in 1579; Gallo Islaud, where Pizarro drew the lino on tho sand, orer which thirteen of his followers crossed; this famons round dozen belioving in their leader; Gorgona, the pleasant island to which this same leader retreated after learing Gallo, and whence he eailed to conquer Peru. ${ }^{+}$

Entering the Bay of Panama wo pass the beautiful Pearl Islands, which haro been well described as a perfumed archipelago, lying like baskets of flowers on the tranquil surface of the occan. To tho castward lies the Gulf of San Miguel, where Balbon, after a journey of twenty-fire dass across swamps, rivers, and woods, which had norer been passed but by the straggling Indian, took possession of the Pacific Ocenn in the namo of the King of Spain and the Indies. Memories of old times and scenes are a little ranning array with me, but there is really a great adrantage in being able to kecp close to these shores, for not only is the current faronrable in the passage to Panama, bnt as it is a branch of the cold Peravian Stream, a plcasanter temperaturo is enjoged than when farther from the coast.

I must, however, in justice, obserro that rains aro at all times frequent, and that onr trip should be so timed as to pass this coast in the fine scason when, as old Dampier sajs, "the rains are moro mode"rato than in the wet scason, for then it pours as out of sieve."

Pansing at Panama, let us reflect apon tho advantago to English commerco of continuing the surrey (so well began, by Sir Henry Kellett between Panama and Guayaquil) from Guajaquil to Cape Pillar at the entrance of the Strait of Magellan. Tho trade of this part of South

1 Jr. Clements Jiarkham, in his "Rcports on the Discorcry of Poru," published by the Irablurt Socicts, belicres sirteen to be the correct number, including the pilot Ruiz, Tho returned to Panams to obtain another Tessel. 
America has increased in a marvellous manner, through the great rovolation which the introdnction of stenm has made in the system of transport of goods by sea. The enterprise of the Pacific Stean Navigation Company has diverted tho trado from tho Isthmus of Panama towards the natural channel of the Strait of Magellan. So successfal has been this new current of trade, trarel, and commerce, that the Company's fleet of magnificent steamships barely suffices to meet the demands of the extraordinarily developed commerce of the South Pacific.

In a statement of the steam companies engaged in the trade of the Pacific Coast, from a Report made by the Statistical Offico of the Repablic of Chile, Valparaiso, 16th September, 1874, wo read as follows :-Pacific Steam Navigation Company; 56 steamers; South American Steamship Company (nativo line), 10 ditto; German, "Kosmos," 6 ditto; Belgian, 4 ditto; Whito Star Line, 4 ditto; Compagnic Générale Transatlantique, 3 ditto;-total, 83 steamers. The steamships of the first-named company made 45 rosages from Liverpool and back, the gross reccipts being siated at three million dollars for cargo; nearly $2,000,000$ dollars for passenger-, and 120,000 dollars for postal-serrice. Altogether 524 vojages on the coast, and 124 to Europe were mado by the various steamers enumerated. This year the depression in financial centres has led to some of the above lines being withdrawn from the trade on this coast, and the Pacifie Stcam Narigation Company hare largely redaced tho number of steamers crnplojed on their line viâ the Straits of Mragcllan, the sailings now being fortnightly in lieu of the weekly scrrice carried on last year.

The annual cost of carrying on the surroy of the coast of South America would, I beliere, bo about $\$ 14,000$ a year, a little less than you willingly allow to be spent on some experiment in shipbrilding that may, or may not sncceed; while of the success of this survey, there can be no doubt, for not only would you be constructing charts for the benefit of the mercantilo navy; but, as I shall presently show, you would bo establishing a first-class finishing school, which, in giving 5our Naral Officers tho opportunity of putting into practice what they had lenrned at Greenwich, would erable them more effeiently to protect the trade they were helping to create. From the praiseworthy efforts which tho Chilian Goverument are now mnking to improse our charts of their coasts, I feel sure of their assistance and co-operation in this work. They would be only too glad to send thcir Officer's to school in our ressels, and thus, after a few years, wo should be able to carry out the dream of a political economist and "let the Chilians survey " their own consts." 1"

Looking northward from Panama, there is moch work to be done. The rising trade of the Central American ports calls for more attention to coasts, of which, when to the northward of the Gulf of Fonseca, we haro little information sinco the days of Mralaspina in 1794. I am glad to be able to state that during January wo receired American

'In the "United Serrice Gazette", of 30th Januars, it was stated that the Naral Department of the Chilian Gorernment bad organised three bydrographieal explorations on the coast of Chili. 
surreys of the coast and Gulf of California which will enable me to shade those shores.

In the North Pacific Ocean, that centre of commerce, the Sandwich Island group, is, I regret to have to point out, unshaded. Our chart of that gronp is said to be "from varions but imperfect anthorities." Captain James Cook who, considering his short stay, gave us, in 1778-9, a good exploration; and the United States exploring expedition in 1841, added to our knowledge of this archipelago. Something better is, however, required in 1874 .

Bat I must push on from Panama, or we shall not get round the world to-night. From Panama, we shape our course for Tahiti; passing the Galapagos, which may bo considered as sufficiently well surveyed for the time, we como next to the Low Archipelago in which the three symbols are blended. What is first wanted here is to examine certain tracks which ships are likely to follow in their passage from Panama, or Valparaiso, throngh these dangerous patches of coral. The comfort such a rond wonld give to the sailor is something beyond a landsman's understanding. Leaving the beautiful and famous Tahiti, where you will all remember Captain James Cook observed the Transit of Venus in 1769 , wo pass on through the Friendly Islands and Fiji archipelago. Here reliable charts are much wanted to clear away the donbtful dangers of this part of the Pacific, which render the nights of the captain as uncomfortable as those of a parish doctor in a poor neighbourhood. He is always being called, has to turn in all standing, which means in plain English, going to bed in his boots.

Many of my hearers will remember the graphic account of the discomforts of shipwreck among the Fijis given by the Earl and the Doctor. Their schooner was, I think, wrecked near the Exploring Isles in the eastern part of the group.

Commodore Goodenough, ably assisted by his industrions Navigating Officer, Lieutenant Hosken, is doing his best to improve our charts of this archipelago; but his praiseworthy efforts show only too clearly how much a surveying vessel is required in Melanesia.

Refreshing ourselves at Sydney, we next push northrards for Hong Kong; our course lies through portions of the ocean similar to those we have already passed; our charts of this part of the world may be said to be, in a great measure, supported by voluntary contribations. Captain Simpson and Narigating-Lieutenant Greet, in the "Blanche"; Navigating-Lieutenant Tilly, of the mission schooner "Southern Cross"; and lately Captain John Mroresby and his navigator, Lieutenant M Mourglian, have all sent additions to our charts. Captain Moresby has been very energetic on our behalf,-obtaining first the serrices of Navigating-Lieutenant Conner, of the Queensland Surver, and latterly those of Lieutenant Dawson, our itinerant surveyor of the south-western Pacific;- he has been enabled, through these Officcrs, to forward considerable information regarding the shores of New Gainen; following up the discoveries of Bougainville and Dentrecasteaux, Captain $\perp$ roresby has charted about 300 miles of the hitherto almost unknown western coast of this island, and has made important additions to the Admiralty charts. Notwithstanding, however, the 
efforts of theso wortliy contribntors, our captain's anrictics aro not decreased, and it is not until wo get to the northward of the Carolines that ho can, for a season, direst himself of his boots.

Our passage is now moro free from dangers. Passing through the Basheo Channel, we enter tho China Seas, refreshing ourselves at Hong Kong. Leaving that port, wo observe an absence of shade to the castward, and traders between Hong Koner and Sydncy wonld be grateful.for better charts of the Xindoro Straits and the passages through the P'hilippine Islands. Coaling at Singapore, we hear that merchantmen aro asking for better charts of the Carimata Strait and the Java Sea.

Lutering the Indian Occan, by the Straits of Mralacen, our next port will be Point de Galle. I will hero pause to thank JIr. Clements Narkham for calling attention, in his Magazino of July last, to the state of tho Coasts of India, littlo having been done to the charts of this important portion of our dominions since 1862, when the Indian Navy ceased to exist; and the charts, copper-plates, and original drawings wero transferred to the Admiralty. Mrr. MIarkham tells us "it was suggested, but not arreed to, that the futare surveys of the "Indian Coasts should bo conducted by the Rosal Navy:" The very few surreying ships that the Admiralty were allowed to equip had other work to do, the Impcrial Treasurs having no intention of paying for Indian survers.

You will be pleased to hear that Lord Salisbury has here como to our assistance, and that a surreying force, consisting of firo sailing vessels taken from the marine serrice at Bombay and Calcatta, will at once bo established. Each sailing rcssel will be supplied with a steam pinnace, and there will be one steam tender; the flotilla will be officered by one Staff-Commander, three Navigaling-Lieutenants, two Navigating Sub-Lientenants, with Mr. R. C. Carrington, lato firstclass draughtsman of the Hydrographic Department, as Chief Civil Assistant. This force has been organized br; and will bo placed ander the superintendence. of a Tell-known Indian Offecr, Commander A. D. Taylor, who will do his best to restore the efficiency of the old Indian Mlarine Surress, and malse prorision for the fast-increasing commercial necessities of British Inciia.

From Galle wo proceed to Aden, and up the Red Sea. I regret being wable to mark the shores of this sea nith the dark line. A beginuing has, howerer, been made; Captain Nares has surveyed the Galf of Sucz, and Lientenant Gray the small Strait of Bab-el-man-deb; bat I haro little doubt the trado through the Suez Canal will enforco this work. Thanks to Monsieur Lesseps, we need not leave our ressel, but may steam into the Mediterrancan where, not to weary you farther, wo will land at Brindisi and raminate orer what wo laro seen and heard. This voyago ronnd the world will have giren you an idea of how much is required to bo done. We will next consider who there is to do it.

I fear if I pipe "Chart-makers to muster," there will hardly be snfficient for the work, especially if wo look to tho main line of the Nary, where onls two Captains, one Commander, and two Lioatenants 
cnn bo found who may bo called qualified to command surreying ships. Tho Retired Lists rould add some four or five Officers to our forces, bnt I fear their services are no longer nvailable. In addition to these Officers, there are nine Staff-Commanders and three NavigatingLieutenants, who may nlso be in some measure qualified; for it must be remarked that, it having for somo time past been considered expedient not to giro Navigating Officers tho command of surveying slips, they can bo employed only as leaders of detached parties. Their instractions are to charter small craft in the colonies, and, with a hired crew and one or two assistants, work round the little circle of which their head-quarters is the centre.

This detached system chicly recommends itsolf by its cheapness, and as an auxiliary force is, I admit, not without value; but it tends to isolate the Surveying Serrice from the general service, and naturally inclines the Officers connected with it, to feel coloninl rather than inipcrial interests.

Another disadrantage of these detached parties is, that we lose that grand school for practical nautical surveying, viz., a ship and the disciplined life of a man-of-war, whero alone a young . Oficer can acquire the combined knowledgo requisito to qualify him for a profession in which the duties of the sailor can by no means be neglected. No man can expect to attain a trusted position as a Nautical Surreyor who is not essentially a good Officer and sailor, or, to speak more exactly, a good Pilot, bnowing how to handle a body of men, the requirements of a ship, and the room she wants to wear, stay, or anchor in. This knorrlcdge cannot bo acquired in, what a naval paper has well termed, "tho one-man-and-a-boy system" of nautical surveying.

It was with great regret, therefore, that, in the middle of 1873 , men, like Sir Bartle Frere, who took an interest in this important brancl of the Navy, saw it had fallen so low that there was only one regular survering ship in commission, viz., the "Shearwater," under Commander Wharton, then on ler passage from the survey of Sicily to assist in tho Zanzibar espedition.

Tho "Challenger," Captain Nares, was, it is true, also in commission; bat she must bo looked upon rather as an exploring than as a surveying ressel; at tho same time, under Captain Nares, and his indefatigable Chief of the Staff, Staff-Commander Tizard, a school was formed from which the best results may bo expected,

Tho total number of Officers cmplojed at this time, Jul5, 1873, was, including the "Challenger's," 36 , of whom four only belonged to the main branch of the service, i.e., there were only one Captain, one Commander, and two lieutenants among the number.

Let as now go back for a quarter of a centurs, to 1849 , tho days of Sir Francis Beaufort, when the public took a greater interest in the Surrejing Service. Wo find that there were no fewer than 12 surreying resscls in commission, in addition to 23 Officers, borno on ships' books for detached Surreying Serrice.' At the same time the Arctic

"If in 1819 a full list of "Offeers employed on surreying serrico" had bcen 
force (the "Challenger" or additional scientific force of the period), numbered three ships, exclusire of the "Ercbus" and "Terror."

I hare here a list of Captains and Commanders, who in 1849 might have been considered qualified to have taken charge of a survey. The number is a large one, viz., 17 Captains and 12 Commanders: as the names are tolerably well bnown, I think reading the list will interest many of my henrers.

\begin{tabular}{|c|c|c|}
\hline Captains. & Commanders. & $\begin{array}{c}\text { Surrcying Ships } \\
\text { of } 1819 .\end{array}$ \\
\hline $\begin{array}{l}\text { Barnett. } \\
\text { Bayficld. } \\
\text { Belcher. } \\
\text { Becclacy. } \\
\text { Bullock. } \\
\text { Collinson. } \\
\text { Denliam. } \\
\text { FitzRos. } \\
\text { Grares. } \\
\text { Kellett: } \\
\text { Owen. } \\
\text { Slicringlaam. } \\
\text { Stanles. } \\
\text { Stokcs. } \\
\text { Suliran. } \\
\text { Fidal. } \\
\text { Washington. }\end{array}$ & $\begin{array}{l}\text { Bate. } \\
\text { Bedford. } \\
\text { Drurg. } \\
\text { Frazer. } \\
\text { Orlebar. } \\
\text { Nollotl. } \\
\text { Otter. } \\
\text { Richnrds. } \\
\text { Shortland. } \\
\text { Spratt. } \\
\text { Williams. } \\
\text { Wolfe. }\end{array}$ & $\begin{array}{l}\text { "Aclucron." } \\
\text { " Aron." } \\
\text { " Bramble." } \\
\text { " Columbia." } \\
\text { " Comet." } \\
\text { " Ircrald." } \\
\text { " Pandora." } \\
\text { " Rattlesnake." } \\
\text { " Rojalist.", } \\
\text { "Scorpion." } \\
\text { " Sparrow." } \\
\text { " Volage." }\end{array}$ \\
\hline
\end{tabular}

It will be obsersed that I hare given a list of Captnins and Commanders only; omitting tho Lieutenants and Mrasters employed in 1849 ; many of whom were also qualified to command sarresing ships.

I have taken 1849 by chance. I am not suro that it was a year in which the Surveying Service was in a particularly flourishing state: 1873 was a bad year, the minimum was arrircd at of one slip; a fact, cracl enough to arouse the shade of Sir Francis Beaufort; and it is easy to imagine that reteran Surveror upbraiding his countrymen, and saying, with Cæsar Angustus, "Oh, Varus, restoro me my legions."

I will next proceed to show that theso ships of 1819 , as schools, produced not only Nautical Sarregors, bat superior Offecrs for the general serrice.

Take the "Acheron," commanded by Captain John Lort Stokes, then surveying New Zealand; in this same "Acheron," the late Hydrographer, Admiral G. H. Richards, was Commander, and Chief of the Staff; the present Hydrographer, Captain Evans, was the MIaster, and his present Chief Naval Assistant, Staff Commander Pender, a Mraster's Assistant.

Tho Captain of the "Encounter," Richard Bradshar, the Officer at first especially selected to take the observers for tho coming "Transit of Venus, to Kerguelen Island, was also a Mlidshipman in the "Acheron."

giren, similar to the one in the present Nary List, it would hare included upwards of 80 names. 
Take the "Herald," then, with the "Pandora," sarreying the great Bight of Panama, uuder Captain Kollett and Licutenant James Wood. The Captain of the "Herald" is now Sir Henry Kellett, K.C.B., lately Commander-in.Chief on the important China station.

I may hore remark that the present Commander-in-Chief in China, Sir Charles Shadwell, K.C.B., Fellow of the- Rnyal Society, was First Lienterinnt of the "Fly," Captain Sir F. Blackwood, daring the snrvey of tho enst coast of Australia and Torres Straits; whilo Admiral Ryder, the fature Commander-in-Chief in China, received his carly education as a sailor and navigator under Captain Richard Oren, in the "Thunder," the surveying ship in the West Indian station in 1833.

Returning to the "Herald," lier First Lientenant was Rochfort Magaire, who finished his career as Commodore of the Anstralian station. Tho Second Lieutenant commanded ono of tho Arctic ships in 1853. The Mlaster of the "Herald," after leaving that ship, serred as Uaster of Sir George Seymour's flagship in tho West Indies. Of the Midshipmen, onc died as Captain in charge of an Australian Surrey, one has lately retired after commanding two surveying ships in succession; anotter is Captain Bedford Pim, who I nm pleased to find on becoming MI.P. has by no means ceascd to lo R.N., or forgotten his nino year's' service in'H.MI. Snrreying Service; and last and least of the old "Ierald's," is tho humble individual who has the honour to nddress you, then a Master's Assistant, now Superintendent of Admiralty Charts.

I havo taken two instances only ont of the surveying ressels of 1849 ; I am saro that most of them wonld tell a similar tale. Sir John Glover, of Ashanteo fame, was serring about that time as a Alate on board tho "Volage," then surreying in tho Mediterranean.

There is nnother interesting branch of the profession of Nautical Surreying, which becomes of the greatest valno to our merchants in this ago of sabmarine cables; I allude to deep sea soundings, and to an examination of tho bed of the occan for the purpose of laying those useful communicators. On the lst of June last year, at a meeting of the Royal Geographical Society, the wall of the theatre of the London University was covered with diagrams, showing how much work the "Challenger" had done in deep-sca sounding. Great was Lord Hown's victory of tho lst of June, 1794 (a day nerer to be forgotten by the English sailor), and the memory of the day was rell kept in 1874, by exhibiting tho trophies of a victory orer tho elements of which Captain Nares may no less bo proud. By the diagrams Dr. Carpenter illastrated an instructive paper, and I beliere, proved the correctness of some of his ingenious theories.

Many of you know the care, forethonght, and experience required in "overcoming the mechanical difficalties" of obtaining an accurate decp-sce sounding. Sounding was erer a most important point in a sailor's profession. "Upon the accuracy of the soundings engrared on the Admiralty chart, the character of the Nautical Surroyor mainly

A phraso used by somo of our philosophers, who, although knoring a for of tho secrets, cannet be said to comprehend the mysters of the sea. 
depends, for whilo the land work may be done by the soldier or ciri! cngineer, the sounding is the sailor's portion, requiring all the reads wit and tact of his profession. In sounding, the sailor has to manage air and water, tho. rise and fall of the tides, the relocity of currents, and to fit in his work to suit wind and weather; these forces becoming firm allies to the man who studies them, and foes only to him who hnows not how to nse them.

Readers of Marrsat will remember the Master of the old war timo was often called "Soundings" by his shipmates. The namo might not haro been meant as a compliment, but it nerertheless mas so. This prime duty of a Nautical Surrejor is now of more value than ever. T'elegraphic Engineers not only require accurate position and depth of water, but also samples of tho bottom of the sca at great depths, they want to know what hind of bed their cables are to lic upon, and this information can be obtained only by sounding.

I am glad to obserro that tho part of Sir Bartle Frero's letter, shoming the adrantages of an expedition to the Arctic seas, has been attended to. The fact of our last Aretic Lixpeditions having brought to the front such men as MrcClnre, MrcClintock, Mnguire, Michards, Osborn, Armstrong, and Nares of the "Challenger," may lead us to hope that the present attempt to place the Union Jack on the northern meeting of the meridians, may bring into notice another body of English sailors, who shall worthily fill the place of thoso now passing arras, and I feel sure nono will ercr regret again raising tho cry of "Northward Ho!"

But thero is one more point I should like to call your attention to, and that is to another body of men the Survoying Service has brought into notice; a class that many (and probably with good reason) would esteem more highly than the simplo sailor; I allude to naturalists and botanists; and when I assert that sach men as Darwin, Hooker, and Huxley, began their celebrated careers in Her DIajesty's surveying and exploring vessels, I hope the public will think it worth while to restore the old practice of appointing a naturalist to surveying ships, on the chance of securing men of such andonbted value to the scientific world.

Professor Ty rville Thomson's staff, now qualifying themselres for theso important duties by sea serrice in Her Mlnjesty's ship "Challenger," leads as to hope that the surrosing ressels of the fature will carry a natumlist, as in the dajs of Sir Francis Beaufort; and I was much pleased to observe in Captain Taylor's schemo for re-cstablishing the Indinn surveys, that be pointed out the ndrisability of again appointing to erery surreying ressel a Nedical Officer, who is also a naturalist, and giring bim encouragement and opportanity to pursuc his scientific tastes.

I trust, Sir, that $I$ have now fully prored the corrcetness of the assertions of Sir Bartle Frere, in his letter to Mrr. Gladstone, viz.: "That "there are few better schools than a Surreying ship; and that if "sach ships-were multiplied, not only would commerce benefit, bat. "our men-of-mar rọould be better supplied with practical seamen." 
Wo lave now considered what may be termed the ont-door work of the Surreying Service. Wo must next turn to the in-door portion.

The harrest may bo plentiful, tho labourers hardworking and willing, the corn is cut and stored, bat before we can nse it for food, it must bo threshed, ground, and mado into bread. $\Lambda$ s with corn so it is witl nantical surreying. Tho rork comes home, it has then to bo giren to the world in the shape of Admiralty charts.

This distribation of knomledge is placed in the hands of tho $\mathrm{H}_{5}$ dro. graphic Office of the Admirnlty, which unfortanately, through the rigorous system of economy insisted upon by the public, has not been permitted to adranco with the times.

Tho number of charts increases yearly, the work required is moro finished and elaborate, the demand and sale of the charts also increases, but there is no corresponding incrense in the Staff employed. In the beginning of 1874 the Ofice suffered two considerable losses, the lato Hydrographer, Admiral hichards, being carried off to the chair of the Telegraph IIIintenance Company; while tho Japanese Government induced one of our best. draughtsmen (holding through the present rules of the Ciril Service, with regard to age, a junior appointment, bat who had actually served four jears in the Scottish Survey, and ten years at tho. Mydrographic Office), to leave $\$ 150$ per annum in England for $\$ 1,000$ per annum in Japan. At the end of tho year, wo also lost our first class dranghtsman, whom Captain Taylor persunded to join tho Indian Mrąrine Surrey; as, however, this loss to us will be gain to India, we can console ourselves by knowing that Mr. Carrington is only serving the Indian instead of the Imperial Government.

Without entoring into the general work of the Hydrographic Office, I will renture to make a few remarks upon tho particular and im: portaut branch of the Department over which I hare the honour to preside.

The old surreyors, who are present, will, I think, quito understand the mingled feelings of pride and diffidence which $I$ experienced last year when (on the deatl of my much lamented predecessor, Captain Iloskyn, who may fairly be said to hare died at his post) Admiral Richards placed mo as Superintendent of Admiralty Charts in the chair onco occupied by Mriohacl Walker. The difficulties before mo wero not so much to improvo tho present, as to be equal to the past.

I found myself most ably supported by the gentlemen of tho Admiralty Chart-Room, or room in which tho charts aro prepared for publication; but until I had fairly entered apon my new duties, I had failed to realizo the maximum of work which this branch of the Office had managed to perform, with a minimum of hands.

An inspection of the Admiralty Chart-Room roould prove the trath of tho assertion of the Daily News in January, 1873, that " space is wanted "to spread ont a chart, without having first to remore books or papers "that are at the same time under consideration." The place is rither suggestive of a midshipman's chest, and it is only from a sailor's luck of having been edacated in a midshipman's berth and used in'thns 
"being cabined, cribbed, confined," to utilize every atom of space, that ono is able to cope with this difficulty.

The number of charts at present published by the Admiralty is in round numbers 2,500 , a largo number of which aro continually under correction, for changes in lights and booys, alterations in leading marks, i.c., beacons, natural or artificial, that lead through channels to clear submarine dangers.

These corrections, although small, require the greatest care and experienco to make them; for if such imporlant simplicities aro neglected, and the chart be incorrect in theso essentials, no finish or canning engraving can save its credit; it is benuty withont discretion, a danger " instead of a safeguard to the sailor who uses it. "Any dranghts. " man," says Sir Edward Belcher, "can make a neat showy plan, bat it is aseless if it cannot stand the seamen's test." $\Lambda$ s a very slight orror in the position, colour, aud character of a light or bnoy, or in the insertion of a simplo dot, cross, or figuro mas lead to the grarest disasters, erery mark upon an Admiralty chart must bo delineated by the Hydrographic Dranghtsmen with tho greatest care, and no pains are spared by these gentlemen in their endearour to attain-where it is possible-mathematical exactness, and tolay before the public the labours of the nantical surveyors, explorers, and amateurs, not only of kngland, but of the civilized world; reducing their rarions styles into a comprehensiro system, and thas furnishing the intelligent seamen with an intelligent gaide, which common industry will soon enablo him to thoroughly appreciatc.

For instance, there aro no fewer than 3,710 lighthonses and lightvessels in the world; these lighthouses and light-ressels aro generally surrounded by, what we will term for illustration, a large family of broys. Let us take a well-known place, "tho Downs," or speaking of watering-places, that part of tho coast of England between Broadstairs and Dover. Here we have 3 lighthouses, 4 light-ressels, and about 20 buoys, or nearly 3 buoys to ono light; from this wo may premise that there are considerably over 9,000 buoys that have to be inserted upon the Admiralty charts.

Notices of changes in lights and buoys abrond require carefal translation by some one who not only understands tho language, bat also the subject under consideration. Hero we miss the talented draughtsman before-mentioned; who, in addition to his other qualifications, was also a survejor and an accomplished linguist.

Again, copper plates, when much used, actually wear ont; 4,000 impressions taken from the same plate in four years is a trial even for copper. On an arerage, it may be stated that, allowing for each plato the constitutional threo scoro and ten years, no less a number than 36 plates a.year linve to be re-drawn and re-engrared to keep up the stock. In nddition to the abore, new sarveys requiro new plates; these averago from 40 to 50 a year, making a total of about 80 fresl plates that are required yearly.

Sir Bartle Frere's' address of 1874 informed the Royal Geographical Society that during the past year 77 new charts had been engraved and pablished; 1,620 sheets had receired corrections and additions; and 
the number of charts printed for tho Royal and Mercantilo Navies and use of the world had been 187,248 .

All MSS. and published hydrographic matter received from foreign Governments has to be examined and compared with the pablished charts, to seo if they can be improved therefrom; and in this duty alone considerable labour and experienco are required.

The above constitutes an amount of work which the present staff of a chief draughtsman and firo assistants, is not equal to, and the resnlt is, that the unpublished information is stendily accumulating.

It may now be asked, "But what will the new College at Greenwich do for us?" This question will, I am sure, be answered to your satisfaction this day fortnight, when my friend MIr. Lauglaton will read us 3 paper on the ontline of the studies at the Royal Naral College. MIy own cxperience, as an Exarniner in Nautical Surroying at the College, encourages mo to hopo that it will recollect that it is educating men who are to be sailors themselves, and direct the labours of other sailors. Greenwich cannot educate the whole Navy, it can but select those Officers best fitted to make use of the advantages it offers. In those men, tho College aims at developing tho keenest intellectual insight, readiness, and strength, but-and there is as much virtue in this but as in Touchstone's if-but I say not (in tho caso of Sarreyors) at the expense of their fingers.

Charts have to be projected or built. Our Surverors will do this more craftily and swiftly, and with moro delicacy and precision, with the help of higher mathematics; but a wilderness of $x+y$ will not assist a man who cannot uso scalo and compasses. Greenwich, there. fore, while aiming at tho highest, forgets not tho lowest.

Emerson, commenting on the success of Napoleon, points out in how great a degreo it was dae, to his nerer thinking the smallest detail unworthy of the most carefal consideration; he could draw up an attractive A B C for the King of Rome, as woll as the orders for. a score of brigades. "It is a fivo minutes," said tho Emperor, "that "wins a battle."

Darwin, bimself a sailor, somowhere remarks that, as a man's intellect increases, his instinct decreases. Sailors must not be educated so highly that they lose those instincts which ure tho real cause of our naral supremacy. Remember that the success of the sailor and pilot depends upon a thorongh and ready knowledge of the many-important simplicitics of his calling; sach knowledgo necessarily endows him with that promptness in action, and fearlessness in con. duct, for which members of his profession hare erer been distinguished.

The prblic must remenber that while the Greenwich stadents are aequiring the raluable power of handling bouks and instruments, they should not lose the not mercly raluable, but absolutely invaluablo power of landling men nnd ships. Modern theorists seem to have forgotten that the great use of edncation is to cnable man or woman to earn their liring lonestly in that station on board tho ship of life, unto which the Great Commander-in-Chief has seen fit to call them. A sailor's education, moro than any other, requires lime. The lato Head

voL. XIX. 
Master of Rugloy, and present Bishop of Exeter, Dr. Temple, speaking with large experience as a 'schoolmaster, remarks, "that the indis"pensable condition of success in self-culture is time"; but it is just this condition which is most signally wanting in modern education. The student of our day must almost of necessity acquire knowledge in i harry, bolt it in fact (a bad process for mind as for bods). Ho must learn much, not in order to retain it and make it (to again quote tho Bishop) "part of his understanding," but in order that he may bo able to throw it up, when under the ordeal of the examination room.

Tho College will furnish the understanding of its stadents with arms, but its labours will bo thrown away unless tho country gives tho students a ship in which they can excrcise thoso arms. Tho knowledge acquired at Greenwich is a force to be used at sea.

You have Greenwich ashore; to completo tho business you must havo Greenwich afloat. No occasion to build a ship; thero are plenty at hand; take a ressel like the "Endymion," femoro a few gans to give space for a chart room ; call her the "Greenwich," and send her to sea with her seniors drawn from the College, her youngsters from the "Britannia" (possibly it might be advisable to send the youngsters to the "Greenwich "beforo the "Britannia").

Let her be commanded by some general service mau, in whom might bo found tho united qualifications of sailor, narigator, and gunper, with a staff composed of a known Nautical Surveyor, and two assistants. Send her to work at somo blank portion of the Unsurrejed World, say-the Pacifio. The Fiji or Sandwich Islands will form a healthy ficld for her labours, the passago ont affording timo for the usual drills, for, as beforo remarked, tho duties of tho sailor and ganner must by no means be neglected. Under tho good Providence she would return in some five years time, not only with a cargo of charts, but with men, who in becoming professors had not cersed to bo sailors. For it is in ships only that men can discover the "Secrets of the sen," and it is not with an egotistical, bat with a self-reliant spirit that I quote Irongfellow, and maintain, when speaking of the iea, that-

\section{"Only those rho braro its dangers}

"Ships for sailors" must bo the cry of our $\mathrm{New}$ Greenwich. Let us learn from a well-known character, Mr. Wackford Squeers, of Do-theBoy's Hall, who, when he had tauglit a boy to spell "window" after his own peculiar fashion, viz., "w-i-n, win; d-e-r, der; winder," at ance dispatched him to go and clean it, this bo termed the "practical "mode of teacling, the regular education system."

Do not, thercfore, fall astern of Do-the-Boy's Hall, bat when your

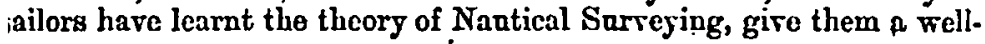

Specimen of the Ideas of Men who do not Comprehend its Mystery: cut from a uceekly paper.

"A suggestion is made to establish telegraph cable stations on the high eas, built upon buoys, at which a steamer unay stop and communicate if in distresa, gire in her time, and enable her paesengers to communicate with their friends on either shore." 
found, and well-mamed, man-of-war to go and praction it, ly making charts of somo portion of the Unsurreyed World.

I have thes endearoured, in the best langnage I can command, to set before you the preseut wants not only of Her Mrajesty's Surreying Service, but of the mercantile world, and ask you to bestow upon this service a little care, attention, and money you give so frecly to shipbuilding and experiments therein, and great gun-founding; for let ships and gans bo perfection, they aro nseless nnless yon have skilled men and trustworthy charts, to couduct your flonting castles with confidence and sccurity.

In conclusion, I appeal to many in this theatre who are fortunate cnongle to possess tho car of the public, and beg of them, if this paper has found frivour in their sight to assist in establishing, on its proper footing, a servico not alone nsefnl in peace, bnt also terrible in war. Tho old Napoleon's collection of maps was probably the best then in existence; with these and his compasses ho planned the destraction of the Austrian forces, and what he had warily conceived in the Tuileries, he oxecuted in tho fold with tho celerity and forco of a thanderbolt. Similarly, tho success of Naral operations often depends npon the correctness of tho charts, coupled with the power tho sailor may possess of constracting and using them.

I woald, therefore, call attention to the necessity of giving Naral Officers early opportmnities of putting into practico aflont what they havo learned on shore; doing, it may bo said, at Ansterlitz what they hare planned in Paris.

linally, I cutreat you all to let this branch of Her Majesty's Serrice be so wall recognized, as a useful element in the Empirc, that it shall be in some mensuro protected from thoso blasts of ruinous cconomy which periodically sweep over our country; remembering that, from its first establishment, the Snrreging Servico has been "secoul to none" in placing and maintaining the Navy of Grent Britain in its prominent position among the forces of civilization.

The Cinsuraras: Beforo I call upon jou to join with me in returning thanks, I hare no doubt there nre znany gentlemen bere who rould lito to male some obser. rations upon the interesting paper wo hare just heard. Captain Shortland, I beliere, is present.

Captain Srontr.skd, R.N.: Our lecturer has sail what he has to say so extremels well that there is rerg littlo to be added. We surrejors know the dificultics that OMicers, who are called upon to survey, lave to contend witl. They do not generalls hare the best slips giren them, nor are their labours so well understood by those who hare not followed surreging as by those who hase, like our worthy chairnan and myself perhaps. We know that we hase fallen rerg much behind-hand lately in the numbers that hare been cuplojed, and the eneouragenent giren to us has not been rery great as far as my experience goes. I hope that the peoplo in power, taking up our worthy lecturer's paper, will carry out some of lis riews and bestow a littlo moro attention to a subject that so well deserres thcir best consideration. I quito beliere that surreying ought not to bo departmental, but it ought to bo considered national. It concerns the whole natiou that we should hare good charts, especialls as our commerce is so rery largo and is estending erery day. If our merchants understood that, it would be the test mode of lessening the insurance on their ships, and I do hope this will be understood in order that the IIouse of Commons una be im. pressed with the necessity of expending a little more money on works which are 
Eo uscful aut esscntiul. Ilowerer, all I hare said is so obrious to cveryone, that it is liardly necessary for me to say it.

Licutenant StrFFe, late Indian Nary : I wish, in tho first place, to bcar testimony to the grcat ability and lnowledge of the snbject shown br Captain IIull, and to the troublo bo must lare taken in getting up that chart. I think, also, tho thanks of the public are duc to lim for drawing attention to the rers important subject of the deficient stato of our knowledgc. For screral reasons, lately, hjdrography has been at a discount, and it has really secmed to me that the raco of hydrographic surregors was going to become crtinct altogether. The chief countries that haro liad to do witl ligdrography hare been England, France, and America. Sinco the ciril war in America, thers has becn rerg littlo done there. In Franco there has been also a collapse during the last few years, oring to the war; and, in England, although the diffeultics hare only bcen financial, set that las apparently been as cfiectual ns any other cause, and wo hare co:ne down it scems, at one time, to onc surreging slip, which is rather an unpleasant state of things to contemplate. I would also mention the abolition of the Indian Narg, to which I had the honour to belong, and the dispersion of the trained group of men that belonged to the surreying branch of that ecrrice, has also added to the deficiency. We may hopo a new ers is going to dawn now, and that a. Ilouse of Commons, more liberal in the true scnse, will see the propricty of taking a fresh start in this matter, and enabling England to maintain her proud position at the l:ead of nautical affairs, and rule the deep with lines of soundings in addition to other methods. Of course, unlegs the publie can be got to understand, clearly, and take an interest in the subject, which can only be done in some such way as drawing up such a map as this, it is hopeless to cxpect any im. prorement in the matter. I lare no doubt many outsiders, on looking at this map, will be rather astonisied to seo so much broicn in the map.' Doubtless they may liare formod an idea that all our anaps and charts were models of perfection and compleleness, and that ererything in print must bo correct; and, therefore, they rill be surprised that so much remains to be done. But I must confess that on looking at it, to mo it is perfectly astonishing thero is so much red there; when one thinks that hydrography and charts on the prescnt system are a thing people now liring cau almost recollect the beginning of. The last half centurs, I suppose, is nearly the whole period, and when one thinks what an cxpenditure of time, energs, labour, money, and life, ercn one of our cliarts often represents, it is perfectl c astonish. ing that so much has been donc. The field is obriously rery large, and I hare no doubt when we hare finished the brown that is shown there, we shall hare to begin again, for the increasing demauds of hjdrographs mill necessitate nen and more elaborate surress.

Thero is one subject Captain Hull has felt obliged to treat rery tenderly, namely, the indoor department of the Hydrographic Ollico. We know it is difficult for a man to complain of the shoo that pinclics limself, and it is not much liked. Perhaps an outsider may say something plainer, and $I$ will say that $I$ think tho amount of space allotted to the Hydrographic Department of the Admirulty is utterly inadequate to the demand, and is unworthy of a country like this. I must say the first time I went there, 12 or 14 jears ago, and ras shomn into the Chart-Room, I came to the conclusion that there nust be suites of rooms, elserwhere, that were not shown to the public, and certainly began to institute a comparison with a prirate ciril engineer's drafting office near Great Gcorge Street, where I was then emplojed, not at all to tho adrantage of the ddmiralty Chart-Room. I must sas, how the gentlemen in that department manage to find anjthing, spread it out for usc, or pul it away again, is quite a puzzle to me. It must be the result of bringing up from clildhood in that nflice, or I do not sco how it is to be done. I think it must bo admitted that a large increase in the staff is a sine quá non. There are, Captain Ifull states, about 2,500 charts now in uso; I should like to know what tho percentage of increase is on what the number was 10 or 20 rears ago, and what is the comparatire increase of tho staff to work these charts. When one thinks that the charts of the whole rorld are mauipu.

1 On the chart exlibited at the lecture, those parts of tho world that had only been explored wero coloured brovon; the fairly surveyed portions were coloured red; and the partinlly surrejed, blice. 
lated and repaired in that small room, it is marrellous how tho work is got through at all.

Mr. FonDE: I had hoped I should hare been allowed to listen to this interesting paper and discussion without baring to speak myelf, as I am not rery much giren to it; but I assure sou, being connected rery much as I am with submarine telegraphs all orer tho world, I haro listened to this paper with the greatest plcasare, and I lope the result of it will be good for us engincers. Wo are often called upon to lay cablcs from ono part of the world to another almost at a moment's notice, andi the first thing wo laro to do is to rush off to the Hydrographer's Department to kvow what information they haro as regards tho locality in question. In $1861 \mathrm{I}$ was engincer to IIer MFajesty's Gorernment for a line laid from Malta to dlexandria. Admiral Washington was, at that time, Hydrographer to tho Admiralty, and wo got the cluarts from liw. 'They looked excecdingly nice; and, as Admiralty charts usually are, rery corrcet, wo had come to the conclusion that we should lay this cable along the coast co as to hare it within reasonable depths, as sorno of tho former cables had been lost in deep water. Wo found, as I haro just eaid, the charts crceedingly pretty, and ve imagined that they were rery carefully done. I was akled bs tho Board of Trade to writo out instructions for the Hydrographer's Department to havo soundings taken, iu order to make quite sure of the depths and nature of the bottom, and in order to obtain soundings at much closer interrals than what is usual on Admiralty clarts. The Adziralty undertook to make theso soundings, and sul asked him, " Hare not you some soundings for us?" Ho said "Ycs, we hare " some, but the information is so incorrect, I dare not send it to you." He ecnt out orders, in the first instance, to Commander Munsell of the "Firely," then stationed at dlezandria, and he said his soundings were so incorrect, or, at all erents, they disagrecd so with published charts, that he had telegraphed to Captain Spratt, commanding Her Mrajesty's ship "IIedina," to go and tale theso soundings. In due cousze, Captain Spritt sent home his first soundings, when Admiral Washington informed is that they confirmed thoso of Commander Mansell, and disagreed entirely with the published charts of that const ; in fact Captain Spratt found great discrepancics. Where tho charts represented tho soundings to deepen gradually from the coast into the IIcditerranean, Captain Spratt found they wero moro like stcps of stairs, going lown 100 fathoms in the swing of a ship. He spent some time orer this, and took partial soundings along the const from Alezandria to Tripoli, nud thence to JIalta. I went to MInita to sce him, and he told me ho bad finislied that service of four soundlings. On examining the charts I told him I ranted a great nany more soundings, to which he replied that my request could not be complied with, as he had already burnt too mich of Her Mrajesty's conls in tho ecrrice of tho Company; but when it was explained to him that this was a Gorerament cable, ho then saw the propricty of burning more coul, and started off agnin for the const, and continued his work for soreral months longer. It appears to mo that the blue colour, on the diagram, is due to Captain Spratt's eerrices on this occasion. Ono thing occurred to me at that time, and I happened to mention it to the Commander-in. Chicf at Malta (Admiral Sir William Martin), ancl that was secing there were so many of Her Majesty's ships sailing all orer the world, why cannot it be managed to have a sounding taken by cach ship at noon; and, in that was, To should soon sce tho whole globe corered mith raluable soundings; whicli soundings would be more or less a guide to engineers who hare to carry out these long cables through decp water. But his answer to that was, "a decp-sen sounding, as we all know, requires to be "taken by a man who has had grcat cxperience in the matter, and who has been well "traincd to it, otherwiso you get false results." Now Captain Inull's paper clearly shows that the nursery for bringing up Officers to surrering has almost been destroyed, therefore we are not likely to haro Offeers, on bonrd cach man-of-rar, that are trained to surrcying and taking decp-sca soundings. I think, mysclf, cuch man of war ought to carry an Officer who has been trained in the Surrejing Serrice, just as they would a gunnery lieutenant. I only hopo that this paper may not only bo brought to the notice of the Iords of the Admiralty, but that they should, if possible, read, mark, learn, and inwardly digest it, with a riew to their carrying into effect Captain IIull's raluablo suggestions. The "Challenger," 
no doubt, is doing good scrvice, and will giro us a great amount of raluablo iu. formation both as to the decp-sea soundings and curreuts, as well as the naturo of the bottom. I will only add that this paper is particularly intercsting to us as civi enginecrs engarcd in laging cables, and I for onc, learfily thank Captain IIull for bringing the subject forward.

Mr. lisogn rox: I liare taken such grent interest in the subject of surreying for some timo past, that it was with great gratification I Iearned tliat Captain II III nas going to bring it forrard; it is one to rhoso needs I am quito suro the country is mot awake. If a copy of the chart now before us could is any may bo published, as in the Als-shect of the "Times," the country would be aghast. Pcople look at the bcautiful maps issucd by Keitli Jolunstone, and othere, and they think that re know the world perfectly: what more can be wanted? They do not know that the outlines giren on such maps are to a great extent mere gucss-work; the proportion of what is real knowledge and of what is imagination is not known cren by well educated men. I most sincerely hopo tho Gorernment may bo able to take the mattcr up, and that Parliament may find them the means to do so. In our small was at Greeuwich I think wo slall, in course of time, bo able to gire a foundation. It is not much we can do with such an entirely practical subject as surrejing; but still we can gire them tho \& $\mathrm{I} C$ of it, and that wo are doing, - I beliere, very cffectuslly.

Dr. HIRST, F.R.S.: It mas not my intention, Sir, to make any renarks this erening, becauso I really did not expect to bo ablo to nttend your meeting. I hare listened sitl rerg great pleasure to the paper just read by Captain IJull, and I hare naturally been greatly intercsted in the allusions ho has male to tho part whish Greenwich mas play in improring the Surrcying Scrrice of the country. There is, I think, but one obscrvation in Captain IIull's address with which $I$ do not hartily concur. Iis warning against our educating Naral Oficers at Grecanich is, I submit, searcely called for at present. If sou take into consicleration the small amount of nn Offeer's time which, under tho most farourable circumstances, can be passed at Greenwich, Jou will, I think, admit-Jr. Darrin would certainly do so-that his sailor instincts are in littlo danger of being thereby dinsinished by orcr-education. IIorcorer, if jou bad been in ny position this afternoon, Sir, and had seen Captain Johnsou's cliss operating with their sertants and other instruments within the railings of Greenwich College, fixing the positions of grarel walks, by means of ungles st:btended by lamp.posts: if jou had scen these Officers aftermards in their class-rooms lajing donn said walks and lamp-posts on paper, constructing, in fact, a clart with as great carc as if the safety of their instructors, when traversing the Quxitrangle cn a foggy day, depended upon the accuracy of their work; if jou had seen this, I say, you would agrec with me that at Grecnwich me do not at all neglect thoso simplicitics of a surreyor's work to which Captain IIull las rery properls directed attention. We certainls do not attempt to riral " $\mathrm{IIr}$. Squeers" in his mode of inparting a practical training. We do not fall astern of him, howerer, in the matter of window-spelling, but we look mainly to the Admiralty to proride opportunitics for window.clcaning. I bcliere, Sir, that the etudies pursued at Grecnwich are without execption those with which erery practical man, properly 80 colled, ought to bo thoroughly acquainted. I belierc that without the iutellectual and theoretical training which re cndearour to girc, the action of a practical man would be incessantly hampered, aud not unfrequently misdirected. I hase, therefore, no hesitation in pronouncing all fears as to the character and teudencs of tho sturtics pursued by liaral Oficers at Grecunich to be perfectly groundless. At tho same time, homerer, I cntircly concur with Captain II lill in the opinion that our work at Greenwicl requires supplementing in the manner he has ndrocated. Operations conducted in the Quadrangle, and cren cstended by means of tho "Arrom" und our stcarn launch to a short distance dorm tho 'Thames are, of course, insufficicnt to mako a surreyor. To this end tho wider experiences which a surrejing ehip alone can provide are absolutely indispensable. Tho praisworthy cfforts of our students to master the rudiments of Wautical Surreging at Greenwich, deserre moro recognition by the Admimlty than they lave as yet rcceircd. Such recoguition, in tho form of specly employment in surrejing ships, would not onls be of great scrrice to the College, but would be velcomed by all who aro interested in the nelfare of our 
Surreying Service. We hare no less than forty Ofliccrs, izcluding Captain, Com. manders, Lieutenants, ard Narigating Licutenants, now studying Nautical Surreying under the guidance of Captain Johnson. Last Session we had about trenty such students, and Captain IIul, who was their Eraminer laet June, was able to report rery farourably of their proficiency. At the head of the list stood Commander Grey, an Oficer who has well qualitied himself for surresing dutics, and who will, I trust, soon bo actirels cmployed in such. In couclusion, Sir, I may state that I cordially join in the wish, to which crpression has been so frequently giren this crening, that the Admiralty may bo indueed epecdily to raiso our Surreging Scrrise to tho high rank it formerly hold.

CLEXESTS MARKIIAY, Esq., C.B., F.R.S.: I, like the rest of the company, have listened with rery great interest to Captain Uull's suggestive paper. I cannot help fccling that it may prore to bo a torning point; that thero is reason to think, from rarious causes, that the surreging brancli of the Naral Servico lins at last reached its lowest depression, and it certainly nill bo a rery great satisfaction to Captain II ull if hercafter, from this ycar, perhaps from this ercning, wo may dato the gradual increaso of the efficiency of the Surreging Serrice of the Nary of this country. In the meanwhile other countrics are doing a little here and there: and $I$ should like to bo allowed to ask, if it is not an improper question, whether, whilst wo are neglecting the work that used to be done on a inuch larger seale twents jears ago, thero is any regular system of collecting from other countrics all the surresing work which is done, sometimes good and sounctimes indifferent, in small patches and in numerous parts of tho world. This kind of work occasionally comes to my knowledge, and I hare often wondered whether, as a matter of course and regularity, it was receired at the Ifydrographer's Office. For thero is mhat appeared to mo a benutiful littlo surrey of tho intricate channels betriecn the Island of Chiloe and the msin land. I know of another surrey on the coast of Peru, executed the ether day. It seems to me that increasingly raluable additions may be made to the charts, by carcfully collecting erergthing that is done by other countrics. I sce, with somo surprise, tho whole of the Wesl Coast of South America coloured brown. I fancied that the chart-shects of that coast mere prepared by $\Delta$ dmiral Fitzros, and that it would hare receircd a bluo colour. If this is not so, I can conceiro no more important wrork thin the complction of the vrhole of that West Coast by a regular surrey, for nearly ercry small part on it is risited by English steamers. Thero was ono lost only tho other day to the north of Callao. Certainly numcrous anchorages and bays, which no oue would erce haro decamed of entering thirty jears ago, are now constantly uscd orring to the incrcasing trade in sugn, cotton, and other exports of Peru. I remember urysclf taking a small ressel into one of the ports of which thero was no sign in tho clart. There is another part of the chart that shows, I think, too much red, which I think should be rednced. India has no right to lare the red completely round her shores, because there are sereral little bits here and there unconnected, and there ought to have been brown epots in at least threc places. \& rery distinguished ciril scrrant of India recently told we he hacl, near Cape Comorin, himself opened a cotton port and despatelued a ship dircet to Fingland from a place cntircly unsurrejed, and unknown as an anchornge. I should like very much to ece Captain IIull's chart reproduced in large numbers, becauso rery few pcople can hare an ides of the immense tract of const that is untonched. I ccrtainly had not. I fancied I should have seen tho whole of that cosst of Soath dmerica, as cramined by Fitzroy, in red; but $I$ only sec patches hero and there. I am sure we ought to be crtremely obliged to Captain Hull for the information he lias impurted to us.

Captain Darrs, R.N.: As an old surrejor myself, and haring been emplosed on the surrey of the coast of Peru, under the late Admiral Fitzroy, I can quite understand why Captain IIull has fired a brown mark round that portion of tho coast that $I$ was cngaged on. I consider the surrey mallo of that part of the coast by Admiral Fitzroy to hare been notling more than a pilot-surves-a surrey of the greatest utility in his day, when such ports as Mr. Blarkham lias instanced were not eren thought of ts being of any importance. Admiral Fitzroy pointed them all out in a simplo running surves, so that I would not at all make the assertion that the 
whole of that coast was properly surreyed. Still, I think Captain Hull might put in a little bit moro red.

Mr. Tretamxx Sutsideng: I wish to add ono mord nith refercuco to a practical conscquence arising from the breaking up, or almost entire brcaking up, of such an cstablishment as that which was carried on with great success uuder Admiral Bcaulfort, and that is the dispersion of a considerable body of trained artisans employed in the engraving of the charts. A body like that is not casily trained; it takes many Jcars of apprenticeship to train then up to the csecution of a work of such excellent character as thoso charts werc; and I must say, when one compares the charts of the present day with the charts exccuted br Admiral Beaufort, I am afraid wo must consider that there has been a decline in the art of cngraring as represented by the Admiralty charts, rather than an adrance. I am quito sure that whenerer a rery considerable increase mar take place in the staff of surrejors, and there is an cndearour to turn to account the large stores of information that remain unused in the Admiralty, a rers considerable diffeulty will be found in procuring competent engrarers, and that is one of the consequences of the economy that has been practised of recent jears in the reduction of this important establishment. I think, Sir, before economies are practised in sucl a way as to disperse trained artisans, the couscquences of such economies ought to be calculated and foreseen.

Captain IIvrs: With regard to the remark by MIr. Forde about the soundings not being found to agrce in the Mediterranean, I may say, the soundings he alluded to tero done in the dass of Admiral Snyth, the great amount of coast cxplored being creditable to the Admiral, but it was, as Captain Daris has rers well remarked, a pilot surrer. I hare no loubt the eoundings of Captain Spratt and, I think, Captain Mansell, will be found to hare the adrantage of being taken by better trained men, who were able to slerote more time to the work.

With regard to whiat Mr. Alarkhism says of the coast from Callao, I think the mork of Admiral Fitzroy's was of a similar character, and in going orer it with the assistance of my friend MIr. Porrell, the chief dmuglitsman, me came to the conclusion that, although wo should hare liked to colour it bluc, i.e., "partially Eurresed," in justice me were obliged to make it brown, or " only cxplored."

I lad not tho least idea of maling any attack on the Kojal Naral College at Grecnwich. I am quitc certain the College is moring in the right dircetion. Tho remarks in my paper were rather directed towards the British public; I fancied from one or two rewarks I had heard lately they wcre crpecting too much from Greenwich; and, with regarl to my allusion to $2 \Gamma$. Squeers, I brought him in as a cort of laugh ut the public. If Greenmich tauglat its students to epcll " window," or surreying ship, Greenwich could do no more. The public should then find the " window," or slip, to clean or surrcy in.

With regart to India, Mr. Mrarkham said some part of India mas not so wcll surresed. I coloured that part of the clant rith the ussistance of Captain Taylor and Licutenant Stiffe. Unfortunately I had never been in India myself, but I shall recollect BIr. Inarkliam's remarks, and, when I prepare the clart for the Journal, I will take care that the part referred to shall bo anended.

The Falkland Islands vere done by Admiral Suliran. Thes are vers tell surresed, and I think are equal to the mants of the times.

Is to the Rirer Plate, portions of that rirer are surrejcd, but ther are unconnected. The rirer has nerer becn fairly surreyed throughout.

The Cramrxas: I am suro you vill join with me in saying we lare had a most interesting lecture, and before asking you to return thanks, I will just make one or two obscrrations. We all are resy well aware that the Battle of the Nile nercy could hare been fought at the hour it was, if Nelson had not himself been a pilot. We are also well awnre, at Copenliagen he took his owa soundings; and, by being able to tako his elips in to a close position to tho batteries, compelled the result of the uction therc. I could quote screral other Offecrs, Bcaufort, for instauce, who, in the courso of the mar, surrejed Liamanis; IIeyrood, who surreyed tho Rircr Plato; but I will allude to one rery celebrated Oficer. A few ycara ago I had occasion to consult the charts of Spitzbergen at the Admiralty, and I came upon one, the last publication, corrected and improred by Captsin Brook of the "Shannon." Now thee are instances I hare brought forward especinlly to call 
the nttention of the junior Oflicers, that a kuowledge of surrejiug, in all probability, may materially iniluence their carecr through life.

I now would proceed in a fer words to allude to the great benefit which the naral and mercantile serrice derircd from tho career of Admiral Sir Fraucis Beaufort as hjdrographer. 'The magnitude of the ignoranco mas cnormous, but, fortunately, we had a man who mas equal to the occasion. Uader his fostering care; the Offecrs in the list which was read to jou to-night mere educuted and well brought up, looking to hin for his countenanec, adrice, and support, and alwass being welcomed back br him with that kindness and affection which is the truo souree of confidence betrecu employer und cmployed. I will just allude to these places which aro non markecl us jou sco them. My first passage round Capo Horn was in the month of March, Gifty sears aro, but then I had nothing to do with lougituries. In tho year 182t I arrired at Rio Janciro with trrelro clurononeters on board tho ship, and we fancied wc had

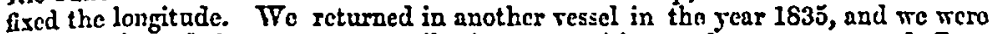
quietly informed that we nere 14 miles in error. Aftcrmards me ment round Cape Horn and tried to carry the longitude up into the Pacific. Our chronometers all went wrong, although me had twenty, and tho fact of tho matter was that tho longitude of the West Coast of South America was not correctly fired, I suppnse, until seamers began to run in 1858 . In the coursc of that royage onc of our objects was to settle the question of the longitude of Mount St. Elias. We sailed from MIazatlan,

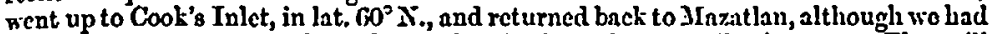
twenty chronometers, wo brought our longitude back to 15 miles in error. That will gire Jou an ides of the difficulty of ascertaining longitudes by chronometers, unless jou perform royages to and fro. In 18.10 we found the Island of Chusan 30 miles out in longitude; and, Laring occasion in 1818, to compare the cliarts at tho mouth of the Ilooghly, I found tho longitude of the entrance, to that rirer, 8 miles in error. That will gire you an ides of the magnitude of the crrors in those dass, nnd what a great a mount has been done sinee that period, and which we mainly owe to the perecrering efforts of Sir Francis Beaufort. Captain Hull alluded to the surTes in South America on which I was employed, and spoke about tho difficulties with the raia, and told you a story about. Daupier. I remember, under tho sarre circundstances, Dampier says that it camo on to rain; and, by great difficulty, they got somo cocos, but, for the life of them, thes could not finish their cups, for it rained so fast.

I think now, Gentlemen, I mas ask you to join with mo in returning our thanks to Captain IIull for the interesting account that he has giren to us, and $I$ am sure you vill cordially agree with mo in thanking him for the able paper mhich be has nritten. 